\title{
〔日本学術会議主催 日本老年医学会共催シンポジウム〕
} 超高齢社会に求められる高齢者医療の担い手の育成 : 教育体制整備へのアクションプラン策定に向けて 一開催の経緯と概要

\section{大内 尉義1 湯村 和子²}

（日老医誌 $2018 ； 55 ： 208$ )

わが国において，超高齢化の進展に対応する医療及 び関連する社会体制の構築は急務である．超高齢社会 において必要な医療とは, 臓器別の専門医療と, 身体 機能，心のケア，さらに生活環境の整備にまで及ぶ広 い視点に立脚した高齢者の全人的医療がうまくマッチ する医療である。このような医療提供体制をわが国に 構築し，またそのための人材育成をはかるために，日 本学術会議において臨床医学委員会の中に老化分科会 が設立され，これまで活動を続けてきた．前期（第 22 期)では, 大島伸一委員長の下,「超高齢社会のフロン トランナー日本：これからの日本の医学・医療のあり 方」と題する提言をまとめ, 2014 年に公表したが, 第 23 期 (2014〜2017)の老化分科会では，前期に行われた議 論をさらに発展させ，「治す医療」から「治し支える」 医療へのパラダイム変換の実現に向け，人材育成，教 育・研究の推進を中心に幅広く議論を行ってきた.

本シンポジウムは, このような 23 期での議論の中 で, 特に時間を割いて行ってきた老年医学の卒前教育, 卒後教育のあり方に焦点をあて，その活動を総括する 目的で企画された。まず，日本老年医学会・楽木宏実 理事長より, 現在のわが国の老年医学の臨床, 教育, 研究の現状が総括され, 次いで, 文部科学省医学教育 課の山口久美子技術参与から老年医学の卒前教育に関
する文部科学省の考え方, 医師でもある薬師寺道代参 議院議員から，議員が以前より訴えている，日本の医 療のあり方における老年医学とその教育の重要性が述 べられた。国立長寿医療センターの取り組みと新専門 医制度における老年病専門医の今後について，それぞ れ荒井秀典副院長, 神崎恒一日本老年医学会専門医制 度委員長による講演が続き，最後に，基幹病院におけ る老年病専門医の活動の場として虎の門病院に設立さ れた高歯者総合診療部の理念と実際の活動について同 病院・井桁之総部長による講演が行われた。いずれも 中身の濃い, 今後のわが国の老年医学の卒前, 卒後教 育を展望し，それを推進する上で大変有意義なシンポ ジウムであった。

なお，本シンポジウム記録をもって，第 23 期日本 学術会議臨床医学委員会老化分科会の活動のまとめと したい.

*第23期日本学術会議臨床医学委員会老化分科会メンバー 委員長: 大内尉義(虎の門病院)副委員長: 鳥羽研二(国立長寿医療研 究センター) 委員: 遠藤玉夫(東京都健康長寿医療センター)大 島 伸 一(国立長寿医療研究センター)小笠原康悦 (東北大学)下門顕太郎 (東京医科歯科大学) 坪田一男 (慶応義塾大学) 松尾清一(名古屋大 学)湯村和子(国際医療福祉大学)横出正之(京都大学)幹事:荒井秀 典(国立長寿医療研究センター)楽木宏実(大阪大学)

1）第 23 期日本学術会議臨床医学委員会老化分科会委員長, 虎の門病院

2）第 23 期日本学術会議臨床医学委員会老化分科会委員, 国際医療福祉大学 連絡責任者：大内尉義 虎の門病院〔テ105-8470 東京都港区虎ノ門 2-2-2〕 e-mail: youchi@toranomon.gr.jp doi: 10.3143/geriatrics.55.208 